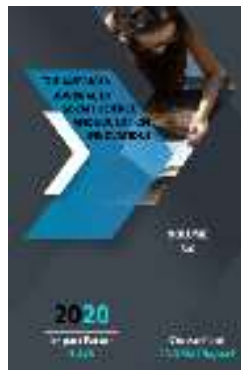

\title{
The Interpretation Of The Concept Of Love Related To Of Human's Emotions In English And Uzbek
}

\author{
Mardiev To'lqin Kulibayevich \\ Head Lecturer Of SamISI (PhD), Uzbekistan , Uzbekistan
}

\begin{abstract}
Journal Website: http://usajournalshub.c om/index,php/tajssei

Copyright: Original content from this work may be used under the terms of the creative commons attributes 4.0 licence.
\end{abstract}

\section{ABSTRACT}

Emotions are an important part of human life. People are subject to both positive and negative emotions. Which one of them is more prevalent depends on a person's lifestyle, his environment and his attitude towards life. It is no secret that only a person can experience a huge amount of emotions. No living thing in the world has such property. Although the disagreements between the learned brethren have not yet subsided, many are inclined to believe that our younger, more advanced brethren are capable of experiencing some emotion. All in all, in this article I would like illustrate the concept of the concept of love related to the human emotions in English and Uzbek languages.

\section{KEYWORDS}

Emotions, love, concept, human, character, cognitiveness, attitudes, types of feelings.

\section{INTRODUCTION}

It is well known that the concept of human emotions is one of the main linguocultural structures that characterize the linguistic personality and the linguistic landscape of the world inherent in it. Attitudes towards human emotions, more precisely, their understanding, are considered to be features that determine the existence of human spiritual concepts. This creates a need for a semantic interpretation of the concept of human emotions. The purpose of this is "to identify its distinctive features, which allow to note the boundaries of its subject area, the essential (essential) features that carry out the hierarchical 
systematization". These signs can be observed in the complex of the concept of human emotions. According to the well-known linguist VI Shakhovsky, emotions are not only expressed, but also illuminated by means of language, consciously expressed. Based on the goal, they conceptualize, verbalize, and gain semantic meaning in speech using words.

The relation of emotion to cognition is defined as follows: "Cognitiveness evokes emotions because it has an emotional nature, and emotions affect cognition because they are expressed at the levels of cognitive processes." Although they differ from each other, they are the two main dimensions of human mental ability and the personal and social aspects of experience. They are interrelated in the structure of the individual. It is well known that no two people on earth will ever meet the same person, or rather, the same person. It is true that some aspects of his appearance may be partially similar (such as body, face, voice), but if attention is paid, this resemblance is relative and does not exactly match. Upon closer inspection, this inconsistency is manifested both in the appearance of man as a biological reality, as well as in his intellect, his emotions, his inner world, and his heart. On medical examination, however, human skin cells are not identical at all. The feeling is also different in nature. Exposure to emotions, events and happenings, mental experiences are within the scope of each person's own natural developmental capabilities, and in this respect they are different from each other.

According to the social nature of man, he sets his own way of life, he is self-governing. He can turn abstract situations into reality through the process of realizing his dreams, aspirations and goals. He can materialize them through interest. Many emotional states, such as good and evil, generosity and greed, greed and cruelty, sincerity and hypocrisy, love and hate, friendship and enmity, define its whole spiritual spiritual value. It is this spiritual world that manifests itself in all the conscious activities of human life, and underlies it the inner spiritual processes. G'.X. Shingarov writes about human emotions that emotion can preserve the most important social emotion while living within its own passions. Spiritual feeling is inherent in man. Therefore, man is by nature a set of feelings and passions. All the passions and emotions in a person, whether negative or positive, have a social character. If a person is able to control his emotions and passions, if he can turn them to goodness with the guidance of the mind, he will be free from all ignorance and hatred. The world of emotions and passions in man in terms of spiritual possibilities can be divided into:

- First, the socio-political feeling. These are feelings directly related to the Motherland, loyalty to independence, national pride and pride.

- Second, the intellectual feeling. It is the brilliance and clarity of thought, amazement, hesitation, reliability and insecurity, acting thoughtlessly to the end, self-deprecation or complacency, and so on. Man sets an example of creativity, ingenuity, discovery with the same opportunity. It shows the power of the mind, the miracle.

- Third is the sense of good and evil. It is a spiritual process associated with feelings of worth, love and hate feelings of envy and jealousy.

- Fourth, the aesthetic sense. It is the direct feeling of beauty, the purity of feelings and emotions, the purity, the excitement, the 
joy, the suffering, the hatred, and so on. It is in these cases that man creates and shapes his whole world. As a result, his whole boot looks the same. Emotion acquires the status of a mechanism through which the mind, the unit of activity, the human will, the power, becomes the character. It manifests itself in man as a synthesis of this trinity. Man embodies the qualities of endurance, tolerance to any reality, events of injustice. In any case, man as a complex being and the intellect and emotions of his character have not received their full appreciation in science. Man's brain, his mind, is so multifaceted, diverse, a state that is difficult to understand and an unpredictable treasure. A unique miracle with incomparable possibilities. This problem is a very complex and perhaps even more difficult phenomenon that science still can't solve.

In general, the science of the XXI century, no matter how many miracles it creates, is weak in the face of the study of the human world. True, unprecedented discoveries are being made in a number of specialized areas. In particular, the computer runs several thousand times faster than the human mind at a glance. Man performs processes that are beyond his comprehension in moments. Robots perform operations that are difficult for humans to perform. But there is no excitement, no emotion, and no emotion. He cannot write poetry, he cannot create novelty, that is, he cannot invent like a human being, he cannot create music, he cannot react to anything, he cannot be nervous, he cannot suffer, he cannot rejoice, he cannot rejoice. Man is valuable in the same way. There is already no color, no scale, no scale, no dimension of emotion and feeling. He has only power and miracles. Emotion, no matter how personal a feeling, acquires social significance through its impact on those around it.

Historical development, the development of society is directly related to the spiritual maturity of each individual, the level of maturity, self-government, self-governance, self-improvement, and so on. The psyche in a person depends on what state he is in. The highness of the spirit leads to good luck in all areas. When the psyche is low, a person becomes depressed. In fact, the role of speech in raising the spirits is great. Positive qualities that elevate any psyche, such as love in speech, sincerity, pure willingness, lead to the elimination of negative vices in the human psyche.

This article illustrates some aspects of the concept of love, which has positive qualities in English and Uzbek. It is well known that there are different opinions in scientific sources about the existence of positive human emotions in the concept of love. For example, in MM Makovsky's dictionary "History of etymological dictionary of modern English" the word love in ancient times meant the connection of all beings, in particular, the overcoming of contradictory relations in life, that is, the gathering of opposing forces and the pursuit of unity".

We know that it is possible to observe that different conceptual emotions are reflected in a person's multifaceted activities. For example, the Homeland also exists in relation to parents, children, relatives. In particular, this feature is clearly reflected in the family relationship between a man and a woman. A typical pattern of human emotions is observed in the family relationship between a man and a woman. This 
trait arises as a result of the family intimacy between the two sexes, which by its very nature is legitimate and necessary on the basis of affection. Just as a family is built on the love and affection between a man and a woman, so a friendship is built on the mutual love of two people.

Based on the analysis of this interpreted lexeme (artistic, philosophical, ethical, religious, everyday), as well as the analysis of the paremia fund, it can be noted that there is a connection between the semantic sign of the concept of friendship and feelings of love. For example, the core of a sense of friendship is love. But the love in a friendship can be formed between several people.

Since family relations between men and women are legal, in Muslim countries, including Uzbekistan, marriage has long been considered a sacred place in society. If the built family is healthy and strong, peace and harmony will be achieved in the society, in the country. After all, family well-being is the foundation of national well-being. Therefore, the role and importance of the family in social life has long been given special attention in the legislation of the state. Such content and need is also reflected in the mental meanings of the concept of friendship. It is therefore undeniable that the relationship between a man and a woman has a great deal to do with the concept of friendship. Because love born on the basis of mutual respect between a man and a woman is associated with friendship. Harmony, intimacy, love between a man and a woman, who are able to get to know each other on the basis of respect, arise because of this friendship. For example, in English I would rather have your friendship than the love of any other woman in the world; some slight remembrance of our friendship and our love would be for ever cherished in her heart. It is clear from this example that we can understand that friendship is also the basis for the continuation of the eternal love that remains in the heart.

There are similar examples in Uzbek. For example, Sadat stayed in the city. I came to the village. When I left, it was as if a piece of my heart was broken in the city. Days later, I confessed that friendship was the prelude to love. In this text, not only friendship, but also the mental meaning of the concept of the heart associated with the feeling of love through the heart equivalent is reflected. This is reflected in the section of the text, "It was as if a part of my heart was broken in the city." In this combination, the pragmatic meaning of "a piece of my heart", "a piece of my love seemed to be broken" is understood.

Also, let's look at the scene of the love affair between Kumushbibi and Otabek in Abdullah Qadiri's "Last Days". It is felt that Kumushbibi's quiet question to Otabek, "Are you that?" In this text, too, the interrelation of concepts such as love, friendship, heart, language as a synonym of lexemes of the heart in the expression of human emotions is felt. A similar situation can be observed in English fiction. For example, His love was more ardent than ever, he loved her for what she was and even, her physical frailty was an added charm in his eyes. In this English text, we witness that human love is expressed through the enthusiasm in their love, the charm in their eyes, and the feelings of charm.

As noted above, in some sources, love has long been viewed as a feeling of divine power, and it is on the basis of this feeling that people are drawn to each other and become close friends. At the same time, the term "divine power" 
should not be understood in the sense of a religious attribute, but in this sense, the material, mental feeling that exists in the human mind.

As noted above, in some sources, love has long been viewed as a feeling of divine power, and it is on the basis of this feeling that people are drawn to each other and become close friends. At the same time, the term "divine power" should not be understood in the sense of a religious attribute, but in this sense, the material, mental feeling that exists in the human mind.

\section{MATERIALS AND METHODS}

Concepts that express human feelings (love, happiness, heart, (heart) friendship) are undoubtedly central to human values. But in the ethics of concepts there is a question of defining their boundaries. Their semantic structure, gender and species identification are also important. The purpose is to determine the importance of the internal system, pragmatic and etymological information.

It is well known that ancient oral and written sources contain a great deal of information, legends, and myths about the mental meanings of human emotions, such as love, which is considered to be the most powerful, both mysterious and magical, and love that arises through love. Love, which is the strongest emotion in man, and the mental meanings in it, have discovered a worldly power in the psyche of the individual, even unknown to himself. This human feeling, old and always young, was equally sacred and holy to all.

Although the sources now have little to do with the concept of love, some descriptions are given and a number of articles and pamphlets dedicated to it are also being created. True, the idea of love in classical works, including works of antiquity, based on the classical typology of love, is given the following types: filia - loveconnection, love - love, love - friendship, love heart, heart represents free individual choice; storge - love-bond, love - sincere, heartfelt friendship, "couple's love", agape - love of loved ones, love without any interest, sacrifice; eros - passionate, emotional love, love focused on full sexual possession.

It should be noted that the etymological features of the concept of love in the Uzbek language are explained to some extent in some sources. In particular, according to the Uzbek scholar Professor E. Begmatov in the "Explanatory Dictionary of the Uzbek language", the concept of love in Arabic means "love, affection, connection." In this case, the person's closeness to a person from the heart, the emergence of a sense of unity; reflects the semantic meaning of love and affection in the human heart: Love is a word, its meaning is the world; Love is the fruit of the tongue; No love ass, no pain - cut.

It is also expressed in affection that giving to someone, something, or work occurs because of a sense of inclination: a love of music, a love of art, and so on. Indeed, love has a thousand different facets, each edge having its own light, its own bitterness, its own happiness, and its own sweet neck.

According to Humboldt and his loyal comrades, "Love is the pursuit of intimacy, it is beauty, and it is about friendship, and love is part of friendship." Hence, in antiquity, love developed towards the perfectionistsympathetic paradigm of ethics, the perfectionist-altruistic paradigm. 
The type of love here is determined by the status and values of the subjects. Different types of love manifest in different forms of friendship. This includes friendship between two different sexes (couple, male and female friendship). In Plutarch, the love of a couple comes first. It is marriage that is sung as the basis of love, while the spiritual unity between a man and a woman leads to love, while the spiritual unity between the same sexes (men) leads to a friendship. It is possible to think endlessly about the family, the rights of the couple, friendship, harmony, and love for each other. Because every family is a unique world. And this world has its own problems of joy and anxiety. Solving these problems is the duty of the head of the family - the land. The Uzbek people have always been an example in this regard. The roles and responsibilities of husband and wife in the family are clearly defined. This is evidenced by the fact that our wise people glorify the position of the father, saying, "The Father is pleased - God is pleased."

If the mind gives birth to respect, the heart gives birth to friendship, the body gives birth to desire. The mind, the heart, and the body are one, and love produces love. Love is one of the most powerful, pleasurable emotions that attack both the heart and the mind and the body at the same time. Such ideas can be observed in the oral speech and paremiological dictionaries of our people. For example, "Love is a word; its meaning is the world. Love is the fruit of the heart. Love is not in the eyes, it is in the heart. Preemie such as "Love is fire" is one of them.

At the same time, love is one of the main individual-psychological features of a person, the emergence of love is also characterized by a direct connection with his client, but the connection between the client and his expression cannot be denied. For example, some of his friends also knew that there was a love bond between Said and Muniskhan; Anwar realized that what had fallen was gold, and felt a warmer love in his heart for the longthinking Rona.

\section{CONCLUSION}

Friendship, love, and family relationships between a man and a woman In English culture, the relationship between a husband and wife is generally viewed on an equal footing. The love in them is determined by the nature, client and behavior of both, i.e. the couple. Although this is also the case in the Uzbek family, the relationship in the family is relatively determined by the nature of the land, the client and the behavior. More than what the husband is happy about and what he likes, the wife will have to take that situation into account, know her husband's behavior, and act on that character. In general, family intimacy between two different sexes is based on love, which by its very nature is legitimate and necessary. A family is built because of the love between a man and a woman. For example, in a family formed as a result of an invincible desire for love, the warmth and light of love ignite the innumerable feelings that bind the two bodies together, blossom flowers; My love for you is still the same. This love is still in its infancy.

Thus, it can be observed that different conceptual feelings are reflected in a person's multifaceted activities. In particular, each of the human emotions has its own mental meanings. For example, the proof of the above-mentioned views is not only in the family relationship between a man and a woman, but also in the relationship between different individuals. 


\section{REFERENCES}

1. Abdullah Qadiri. Scorpion from the altar. - $T$ : Sharq, 2004.-287 p.

2. Abdulla Qahhor. Anor.- $T$ :: “G'afur G'ulom", 2005, 200-p.

3. Abdurozzoqova Sh. Tafakkur gulshani. $-\mathrm{T}$.: G'afur G'ulom, 1989.-462 p.

4. Abdullah Qadiri. Past days.- T .: "Ghafur Ghulam", 1994.-285p.

5. Berdiyorov X., Rasulov R. Paremiological dictionary of the Uzbek language. - $\mathrm{T}$.: Teacher, 1984.- 288 p.

6. Vorkachev S.G. Comparative ethnosemantics of teleonomical concepts "love" and "happiness" Monograph. Volgograd .: Change, 2003-164 p.

7. Vorkachev S.G. Methodological substantiation of linguoconceptology Theoretical and Applied Linguistics. Interuniversity collection of scientific papers. Issue $Z$. Aspects of metacommunicative activity - Volgograd Voronezh, $2002-233 \mathrm{p}$.

8. Humboldt W. von. Language and philosophy of culture - Moscow: Progress, 1985 - $450 \mathrm{p}$.

9. Ismoilov Nuriddin. Muxabbat va naphrat. T "Kafur Kulom", 2013, 304 b

10. Shakhovsky V.I. Categorization of emotions in the lexical-semantic system of the language - Voronezh 1987 - S. 88-100.

11. Shingarov $H$. Emotions and feelings as forms of reflection of reality- M 1971, $157 \mathrm{p}$.

12. Annotated dictionary of the Uzbek language. - M .O'ZSE, $1981632 \mathrm{p}$.

13. Emily Bronte. Wuthering Heights Web site at http://www.planetpdf.com. Page.540.

14. Jack London. Martin Eden -M. foreign Languages publishing house, $1960-440 \mathrm{p}$. 